\title{
Assessment of the Stability of Novel Antibacterial Triazolyl Oxazolidinones Using a Stability-Indicating High-Performance Liquid Chromatography Method
}

\author{
Oludotun A. Phillips Leyla H. Sharaf Mohammed E. Abdel-Hamid \\ Reny Varghese
}

Department of Pharmaceutical Chemistry, Faculty of Pharmacy, Kuwait University, Jabriya, Kuwait

\section{Key Words}

Triazolyl oxazolidinones $\cdot$ Stability $\cdot$ High-performance liquid chromatography $\cdot$ Mass spectrometry

\begin{abstract}
Objectives: To evaluate the stability of 12 triazolyl oxazolidinone (TOZ) derivatives in simulated gastric and intestinal fluids as well as in human plasma at $37 \pm 1^{\circ} \mathrm{C}$. Materials and Methods: A stability-indicating high-performance liquid chromatography (HPLC) procedure with a $\mathrm{C}_{8}$ column $(250 \times$ $40 \mathrm{~mm}, 5 \mu \mathrm{m}$ particle size) and a mobile phase of acetonitrile $/ \mathrm{H}_{2} \mathrm{O}(50 / 50 \mathrm{v} / \mathrm{v})$ at $1.0 \mathrm{ml} / \mathrm{min}$ was used. Accelerated stability studies were conducted at $37 \pm 1^{\circ} \mathrm{C}$ in $0.1 \mathrm{M} \mathrm{HCl}$ solution as simulated gastric fluid and in phosphate buffer solution ( $\mathrm{pH}$ about 7.4) as simulated intestinal fluid. The stability of TOZs in human plasma at a simulated biological temperature of $37 \pm 1^{\circ} \mathrm{C}$ was evaluated as well. Results: The stability studies indicated that the examined TOZs were stable in the above media, with the exception of compounds 1a [tertbutyl 4-(4-((R)-5-((1H-1,2,3-triazol-1-yl)methyl)-2-oxooxazolidin-3-yl)-2-fluorophenyl)piperazine-1-carboxylate] and $1 \mathrm{~b}$ [tert-butyl 4-(2-fluoro-4-((R)-5-((4-methyl-1H-1,2,3-triazol1-yl)methyl)-2-oxooxazolidin-3-yl)phenyl) piperazine-1-carboxylate], which underwent degradation in simulated gas-
\end{abstract}

tric fluid. The degradation kinetics revealed degradation parameters $\left(k_{\text {deg }}, t_{1 / 2}, t_{90}\right)$ of $0.180 h^{-1}, 3.85 h$, and $0.58 \mathrm{~h}$ for $1 \mathrm{a}$ and of $0.184 h^{-1}, 3.76 h$ and $0.57 h$ for $1 b$, respectively. Furthermore, the degradation products were identified by mass-spectrometric analysis at mass-to-charge ratios 347.5 and 361.5 , respectively, and proton nuclear magnetic resonance analysis. Conclusion: With the exception of compounds $1 \mathrm{a}$ and $1 \mathrm{~b}$, the TOZs are stable in simulated gastric and intestinal fluids as well as in human plasma. Being carbamate derivatives, compounds $1 \mathrm{a}$ and $1 \mathrm{~b}$ underwent fast and complete degradation in simulated gastric fluid. The obtained results should be considered for future studies of formulation of structurally related TOZs in oral dosage forms.

Copyright $\odot 2010$ S. Karger AG, Basel

\section{Introduction}

The oxazolidinones represent a novel class of antibacterial agents with potent activity against susceptible and resistant Gram-positive bacterial pathogens. Linezolid (fig. 1), the only member of this class in clinical use, has demonstrated significant success in the treatment of a variety of infections caused by Gram-positive bacteria, including hospital and community-acquired pneumonia,

\section{KARGER}

Fax +4161306 1234

E-Mail karger@karger.ch

www.karger.com (c) 2010 S. Karger AG, Basel

$1011-7571 / 11 / 0201-0051 \$ 38.00 / 0$

Accessible online at:

www.karger.com/mpp
Oludotun A. Phillips

Department of Pharmaceutical Chemistry, Faculty of Pharmacy

Kuwait University, PO Box 24923

Safat 13110 (Kuwait)

Tel. +965 2498 6070, Fax +965 2534 2807, E-Mail dphillips@ @sc.edu.kw 
Fig. 1. Chemical structures of antibacterial
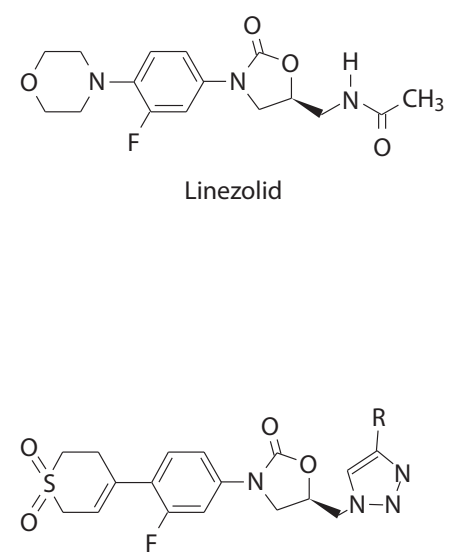

2: $\mathrm{R}=\mathrm{H} ; \mathrm{Br} ; \mathrm{F}, \mathrm{CH}_{3}$

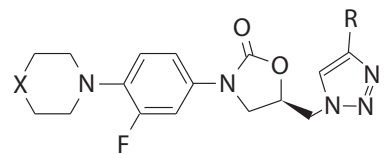

$\mathrm{PH}-027: \mathrm{R}=\mathrm{H}, \mathrm{X}=\mathrm{O}$ 1: $\mathrm{R}^{\prime \prime}=\mathrm{H}$ or $\mathrm{CH}_{3}$

$\mathrm{R}$ = formyl, alkylcarbonyl, arylcarbonyl, arylsulfonyl; etc.

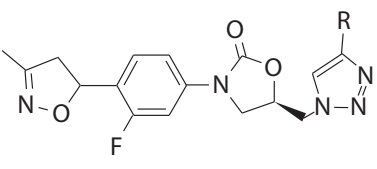

3: $\mathrm{R}=\mathrm{H} ; \mathrm{CH}_{3}$ oxazolidinones.

and skin infections [1-4]. In addition, linezolid showed in vitro activity against selected Gram-negative pathogens, including Moraxella catarrhalis and Haemophilius influenzae. Oxazolidinone antibacterials inhibit protein synthesis through binding to the bacterial $23 \mathrm{~S}$ ribosomal RNA of the 50 S subunit $[5,6]$. Most recently, the crystal structure study by Duffy et al. [7] showed that linezolid binds to the 50S A-site. Moreover, recent reports of linezolid-resistant strains emphasized a pressing need for more effective derivatives with reduced toxic side effects [8-10].

Our previous reports [11-14] and those of others [15, 16] have shown that the replacement of the 5 -acetamido methyl substituents of linezolid with the N-linked triazolyl moiety gave 5-triazolylmethyl oxazolidinone derivatives (PH-027, 1-3; fig. 1) with potent antibacterial activity. Furthermore, recent studies by Reck et al. [15] and Hauck et al. [16] reported that a series of novel oxazolidinones bearing different 4 '-substituted 1,2,3-triazoles at the C5 position of the oxazolidinone (2-3; fig. 1) showed potent antibacterial activity with diminished monoamine oxidase A inhibitory activity. However, selected novel triazolyl oxazolidinones (TOZs) from our laboratory, with potent in vitro antibacterial activity superior or comparable to linezolid, showed 4 -fold or greater minimum inhibitory concentration values against the Staphylococcus aureus ATCC 25923 strain in the presence of human plasma [12-14]. This difference was proposed to be due to either protein binding or instability of the compounds. The application of liquid chromatography (LC) coupled with mass spectrometry (MS) as a powerful tool for analysis of this class of compounds in biological fluids has been demonstrated in many studies [17-20]. Therefore, the purpose of this study was to assess the stability of these oxazolidinone derivatives in simulated gastric and intestinal fluids as well as in human plasma using a stability-indicating high-performance liquid chromatography (HPLC) procedure, and also to identify the chemical structures of the degradation products, if any, by MS analysis.

\section{Materials and Methods}

\section{Materials}

A series of TOZ compounds were prepared in our laboratory according to the reported method [11-14]. Human plasma samples were kindly donated by Kuwait Blood Bank, Kuwait and were stored at $-25^{\circ} \mathrm{C}$. All solvents were of HPLC grade and the reagents were of analytical grade. Water was purified by a Milli-Q device (Millipore, Bedford, Mass., USA).

\section{HPLC and Chromatographic Conditions}

The stability studies were conducted using an isocratic HPLC (Waters Alliance 2695 LC) connected to an Auto-sampler (Waters Association, Milford, Mass., USA). The chromatographic analyses were performed using a reversed-phase $\mathrm{C}_{8} \mathrm{LC}$ column (Waters, $250 \mathrm{~mm}$ length $\times 40 \mathrm{~mm}$ internal diameter, $5 \mu \mathrm{m}$ particle size) and a mobile phase of acetonitrile/water (50/50 v/v) at a flow rate of $1 \mathrm{ml} / \mathrm{min}$. A $20-\mu \mathrm{l}$ aliquot of sample was injected into the system. The analysis run time was about $10 \mathrm{~min}$ and the eluent was monitored at $\lambda_{254 \mathrm{~nm}}$ using a Waters 996 PDA detector at ambient temperature. The peak areas of the eluted compounds were automatically measured by the Millennium software and were used to calculate the percent remaining and percent degradation of TOZ compounds. 


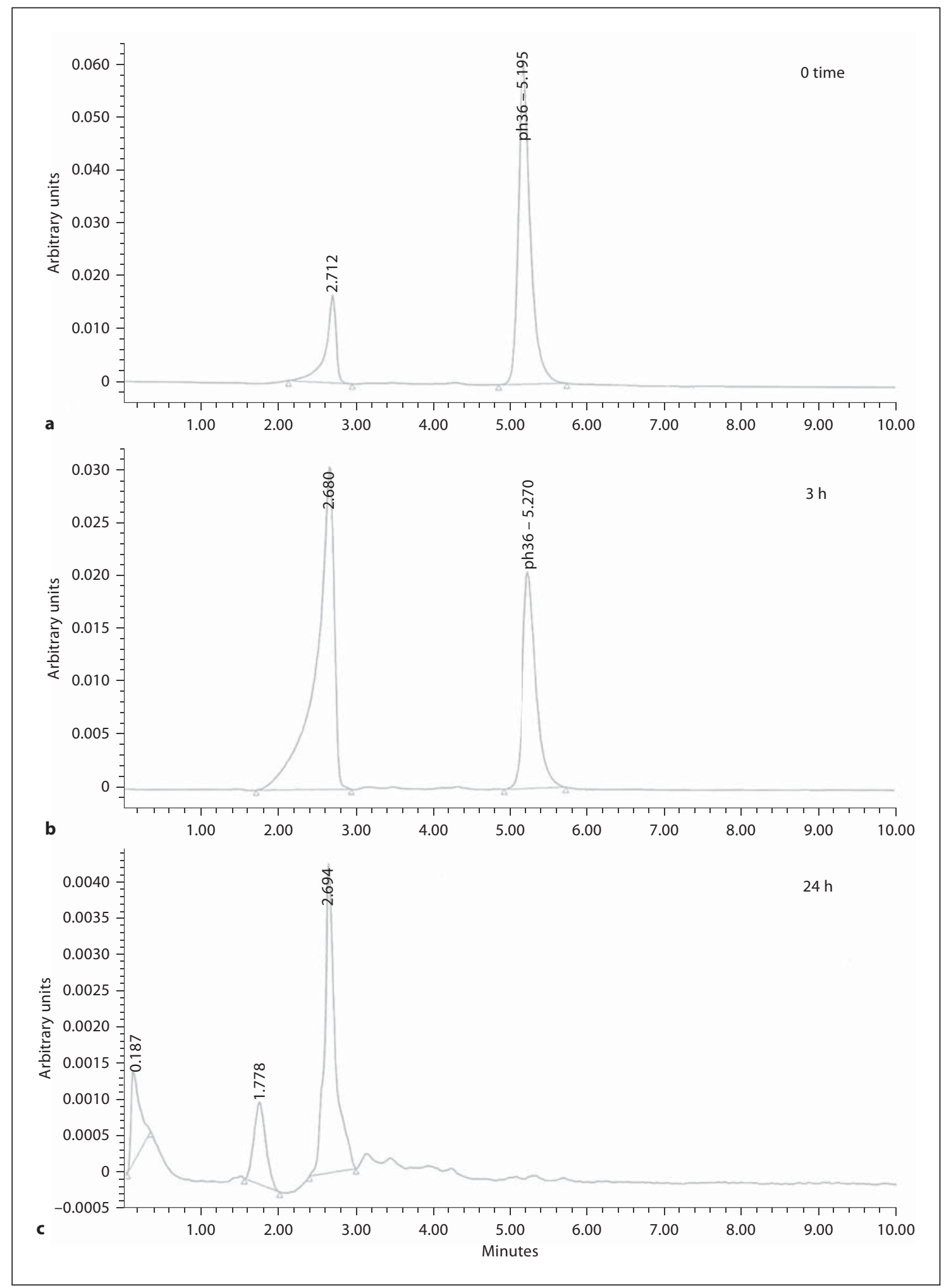

Fig. 2. HPLC chromatograms of compound $1 \mathrm{a}$ in $0.1 \mathrm{M} \mathrm{HCl}$ at $37^{\circ} \mathrm{C}$ at 0 time (a), $3 \mathrm{~h}$ (b) and $24 \mathrm{~h}$ (c). 


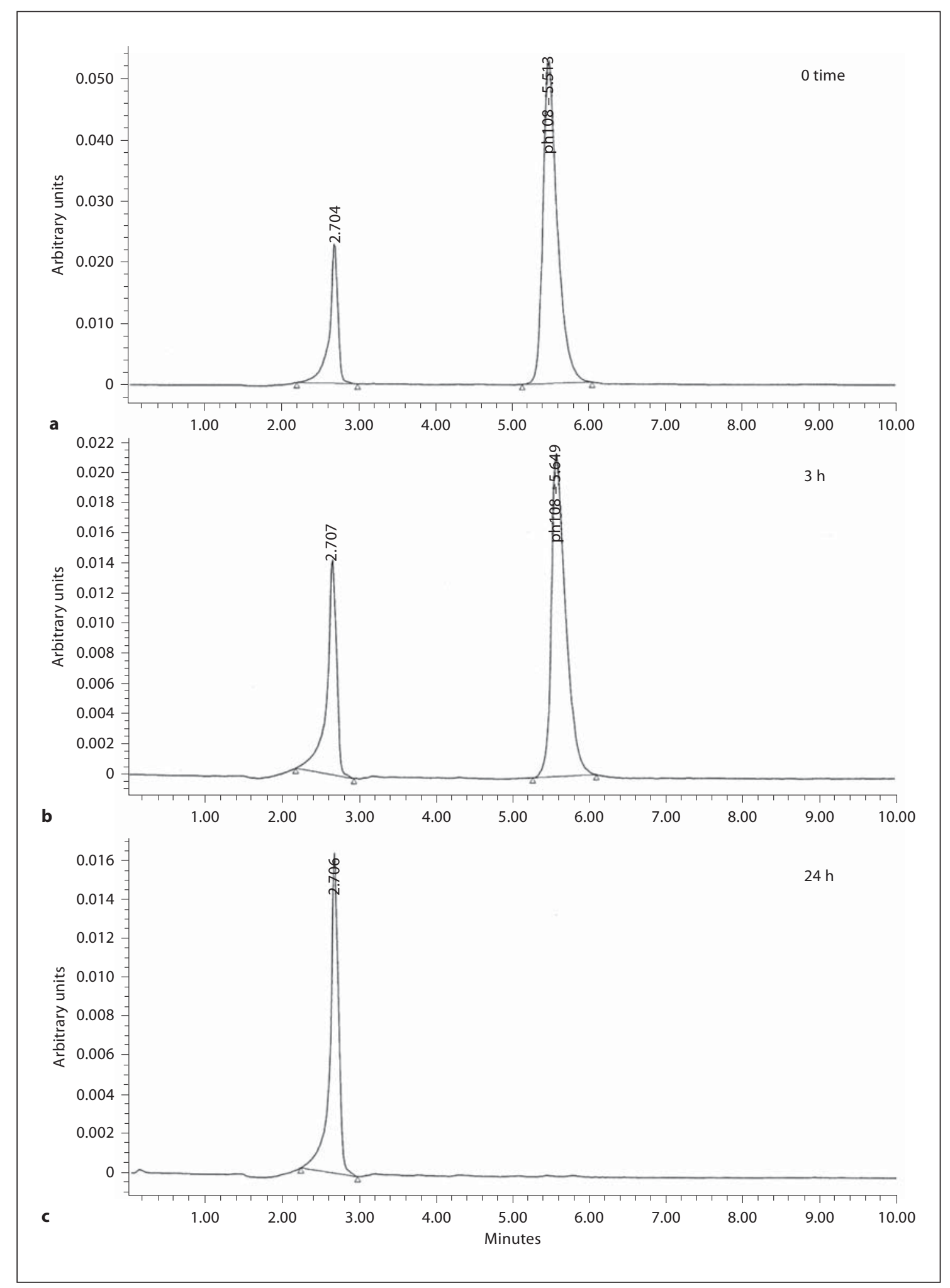

Fig. 3. HPLC chromatograms of compound $1 \mathrm{~b}$ in $0.1 \mathrm{M} \mathrm{HCl}$ at $37^{\circ} \mathrm{C}$ at 0 time (a), $3 \mathrm{~h} \mathrm{(b)}$ and $24 \mathrm{~h}(\mathbf{c})$. 
Table 1. Stability of TOZ compounds in $0.1 \mathrm{M} \mathrm{HCl}$ solution at $37 \pm 1^{\circ} \mathrm{C}$

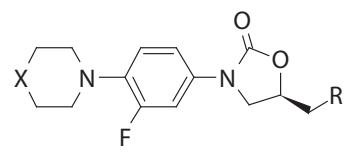

\begin{tabular}{|c|c|c|c|c|c|}
\hline Compound & $\mathrm{X}$ & $\mathrm{R}$ & $\mathrm{K}_{\mathrm{deg}}$ & $t_{1 / 2}$ & $t_{90}$ \\
\hline Lzd & $\mathrm{O}$ & $\mathrm{HNCOCH}_{3}$ & $0.0110 \mathrm{day}^{-1}$ & 63 days & 9.5 days \\
\hline PH-027 & $\mathrm{O}$ & & $5.53 \times 10^{-4} \mathrm{day}^{-1}$ & 1,254 days & 190 days \\
\hline 1a & $\left(\mathrm{CH}_{3}\right)_{3} \mathrm{OCON}$ & & $0.180 \mathrm{~h}^{-1}$ & $3.85 \mathrm{~h}$ & $0.58 \mathrm{~h}$ \\
\hline $1 b$ & $\left(\mathrm{CH}_{3}\right)_{3} \mathrm{OCON}$ & & $0.184 \mathrm{~h}^{-1}$ & $3.76 \mathrm{~h}$ & $0.57 \mathrm{~h}$ \\
\hline $1 \mathrm{c}$ & $\mathrm{HCON}$ & & $0.0198 \mathrm{~h}^{-1}$ & $35 \mathrm{~h}$ & $5.3 \mathrm{~h}$ \\
\hline $1 d$ & HCON & & $0.0212 \mathrm{~h}^{-1}$ & $32.7 \mathrm{~h}$ & $4.95 \mathrm{~h}$ \\
\hline $1 \mathrm{e}$ & $\mathrm{CCl}_{3} \mathrm{CON}$ & & $5.53 \times 10^{-4} \mathrm{day}^{-1}$ & 1,254 days & 190 days \\
\hline 1f & $\mathrm{CCl}_{3} \mathrm{CON}$ & & 0.0166 day $^{-1}$ & 41.8 days & 6.33 days \\
\hline $1 \mathrm{~g}$ & $\mathrm{PhCON}$ & & 0.127 day $^{-1}$ & 5.46 days & $20 \mathrm{~h}$ \\
\hline $1 \mathrm{~h}$ & $\mathrm{PhCO}$ & & 0.0390 day $^{-1}$ & 17.8 days & 2.7 days \\
\hline $1 \mathrm{i}$ & & $\mathrm{N}=$ & $0.0152 \mathrm{~h}^{-1}$ & $46 \mathrm{~h}$ & $6.9 \mathrm{~h}$ \\
\hline $1 \mathrm{j}$ & & & 0.110 day $^{-1}$ & 6.3 days & $23 \mathrm{~h}$ \\
\hline
\end{tabular}

Lzd = Linezolid; $\mathrm{K}_{\mathrm{deg}}=$ degradation rate constant; $\mathrm{t}_{1 / 2}=$ degradation half-life; $\mathrm{t}_{90}=$ shelf life .

MS Analysis

MS analysis of compounds $1 \mathrm{a}$ and $1 \mathrm{~b}$ and their respective degraded compounds was performed using tandem MS (Quattro LC, Micromass, Manchester, UK). The instrument tuning parameters were adjusted to $3.5 \mathrm{kV}$ and $25 \mathrm{~V}$ for capillary voltage and cone voltage, respectively. The source and desolvation temperatures were 100 and $250^{\circ} \mathrm{C}$, respectively. The MS scan was in the range of massto-charge $(\mathrm{m} / \mathrm{z}) 100-500$. Solutions of the examined compounds were prepared in the mobile phase (acetonitrile/water/formic acid, $80 / 20 / 0.025 \%, \mathrm{v} / \mathrm{v} / \mathrm{v}$ ) and injected directly into the mobile phase flowing to the ionization probe of the mass spectrometer at a flow rate of $50 \mu \mathrm{l} / \mathrm{min}$ using positive electrospray ionization mode.

\section{Procedures}

Accelerated Stability Study of TOZ Compounds in Simulated Gastric and Intestinal Fluids. Stock solutions ( $1 \mathrm{mg} / \mathrm{ml})$ of the TOZ compounds were separately prepared in acetonitrile. Eight samples of 20- $\mu$ l aliquots of each compound were diluted to $1 \mathrm{ml}$ with either $0.1 \mathrm{M} \mathrm{HCl}$ (simulated gastric fluid) or phosphate buffer, pH 7.4 (simulated intestinal fluid). The solutions were well mixed, incubated at $37 \pm 1^{\circ} \mathrm{C}$ and an aliquot of $20 \mu \mathrm{l}$ of each solution was injected into the HPLC system. The samples were withdrawn at 0 time and then at 1-hour intervals for $6 \mathrm{~h}$ and then at $24 \mathrm{~h}$ in duplicates.

Stability Study of TOZ Compounds in Human Plasma. A 20- $\mu \mathrm{l}$ aliquot of each compound stock solution $(1 \mathrm{mg} / \mathrm{ml})$ in methanol/ $\mathrm{H}_{2} \mathrm{O}(75 / 25)$ was diluted to $1 \mathrm{ml}$ with plasma/water (1/1). Eight samples of each compound were prepared in diluted plasma and incubated at $37 \pm 1^{\circ} \mathrm{C}$. A $50-\mu$ l aliquot of the plasma sample was withdrawn, at 0 time and then at 1-hour intervals for $6 \mathrm{~h}$ and at $24 \mathrm{~h}$, and transferred into an Eppendorff tube and mixed with $250 \mu \mathrm{l}$ of acetonitrile as protein precipitant. The samples were centrifuged at $980 \mathrm{~g}$ for $10 \mathrm{~min}$ and a $20-\mu \mathrm{l}$ aliquot of the clear supernatant of each sample was injected into the HPLC system. 
Table 2. Stability of TOZ compounds in phosphate buffer solution $(\mathrm{pH} 7.4)$ at $37 \pm 1^{\circ} \mathrm{C}$

\begin{tabular}{llll}
\hline Compound & $\mathrm{K}_{\text {deg }}$ day $^{-1}$ & $\mathrm{t}_{1 / 2}$, days & $\mathrm{t}_{90}$ \\
\hline Lzd & 0.072 & 9.625 & 1.46 days \\
PH-027 & 0.066 & 10.5 & 1.59 days \\
$1 \mathrm{a}$ & 0.05 & 13.9 & 2.1 days \\
$1 \mathrm{~b}$ & 0.077 & 9 & 1.36 days \\
$1 \mathrm{c}$ & 0.0672 & 10.3 & 1.56 days \\
$1 \mathrm{~d}$ & 0.072 & 9.625 & 1.46 days \\
$1 \mathrm{e}$ & 0.193 & 3.6 & $13 \mathrm{~h}$ \\
$1 \mathrm{f}$ & 0.028 & 24.8 & 3.75 days \\
$1 \mathrm{~g}$ & 0.122 & 5.7 & $20.7 \mathrm{~h}$ \\
$1 \mathrm{~h}$ & 0.166 & 4.18 & $15.2 \mathrm{~h}$ \\
$\mathrm{li}$ & $2.76 \times 10^{-3}$ & 251 & 38 days \\
$1 \mathrm{j}$ & 0.0387 & 17.9 & 2.71 days \\
\hline
\end{tabular}

Lzd = Linezolid; $\mathrm{K}_{\mathrm{deg}}=$ degradation rate constant; $\mathrm{t}_{1 / 2}=$ degradation half-life; $\mathrm{t}_{90}=$ shelf life.
Table 3. Stability of TOZ compounds in human plasma at $37 \pm$ $1^{\circ} \mathrm{C}$

\begin{tabular}{llll}
\hline Compound & $\mathrm{K}_{\text {deg }}$ & $\mathrm{t}_{1 / 2}$ & $\mathrm{t}_{90}$ \\
\hline Lzd & 0.0166 day $^{-1}$ & 41.7 days & 6.3 days \\
$\mathrm{PH}-027$ & 0.216 day $^{-1}$ & 3.2 days & $11.7 \mathrm{~h}$ \\
$1 \mathrm{a}$ & 0.0718 day $^{-1}$ & 9.6 days & $35 \mathrm{~h}$ \\
$1 \mathrm{~b}$ & $0.0110 \mathrm{~h}^{-1}$ & $63 \mathrm{~h}$ & $9.6 \mathrm{~h}$ \\
$1 \mathrm{c}$ & 0.0220 day $^{-1}$ & 31.5 days & 4.77 days \\
$1 \mathrm{~d}$ & 0.144 day $^{-1}$ & 4.8 days & $17.5 \mathrm{~h}$ \\
$1 \mathrm{e}$ & 0.0110 day $^{-1}$ & 62.7 days & 9.5 days \\
$1 \mathrm{f}$ & 0.110 day $^{-1}$ & 6.3 days & $23 \mathrm{~h}$ \\
$1 \mathrm{~g}$ & 0.166 day $^{-1}$ & 4.2 days & $15.2 \mathrm{~h}$ \\
$1 \mathrm{~h}$ & 0.127 day $^{-1}$ & 5.5 days & $20 \mathrm{~h}$ \\
$1 \mathrm{i}$ & 0.0277 day $^{-1}$ & 25 days & 3.8 days \\
$1 \mathrm{j}$ & $5.53 \times 10^{-3}$ day $^{-1}$ & 125.4 days & 19 days \\
\hline
\end{tabular}

Lzd = Linezolid; $\mathrm{K}_{\mathrm{deg}}=$ degradation rate constant; $\mathrm{t}_{1 / 2}=\mathrm{deg}-$ radation half-life; $\mathrm{t}_{90}=$ shelf life.

\section{Stability Profiles}

The stability profiles were established by plotting the $\log \%$ of remaining TOZ compound versus time (h). The degradation kinetic parameters, i.e. the rate of degradation $\left(\mathrm{k}_{\mathrm{deg}}\right)$, degradation half-life $\left(t_{1 / 2}\right)$, and shelf-life $\left(t_{90}\right)$, were determined from the stability profiles using the formulas: $\mathrm{K}_{\mathrm{deg}}=2.303 \times$ slope $\left(\mathrm{h}^{-1}\right), \mathrm{t}_{1 / 2}=$ $0.693 / \mathrm{K}_{\mathrm{deg}}(\mathrm{h}), \mathrm{t}_{90}=0.105 / \mathrm{K}_{\mathrm{deg}}(\mathrm{h})$, respectively.

\section{Preparation of the Acid Degradation Products of Compounds} $1 a$ and $1 b$

A quantity $(25 \mathrm{mg})$ of compounds $1 \mathrm{a}$ or $1 \mathrm{~b}$ was dissolved in $1 \mathrm{ml}$ acetonitrile and treated with $5 \mathrm{ml}$ of $0.2 \mathrm{M} \mathrm{HCl}$ solution. The mixture was kept in a water bath thermostatically controlled at 37 $\pm 1^{\circ} \mathrm{C}$ for $3 \mathrm{~h}$. Thin-layer chromatographic analysis showed that the compounds were completely hydrolyzed. The mixtures were then concentrated on a rotary evaporator and crystallized to give white solid masses. The collected powders were analyzed by MS measurements using a $\mathrm{CH}_{3} \mathrm{CN} / \mathrm{H}_{2} \mathrm{O} /$ formic acid $(80 / 20 / 0.025$, $\mathrm{v} / \mathrm{v} / \mathrm{v})$ solvent mixture at a concentration of $100 \mu \mathrm{g} / \mathrm{ml}$. The degradation product of compound la [(R)-4-[2-fluoro-4-(2oxo-5-[1,2,3]triazol-1-yl methyl-oxazolidin-3-yl) phenyl]-piperazine-1-ium hydrochloride] was analyzed by proton nuclear magnetic resonance ( $\left.{ }^{1} \mathrm{H}-\mathrm{NMR}\right) .{ }^{1} \mathrm{H}-\mathrm{NMR}$ (DMSO- $\mathrm{d}_{6}, 600 \mathrm{MHz}$ ): $\delta 8.84-8.94\left(\mathrm{br}, 2 \mathrm{H}\right.$, piperazinium $\left.{ }^{+} \mathrm{NH}_{2}\right), 8.17(\mathrm{~s}, 1 \mathrm{H}$, triazole $\mathrm{H})$, $7.76(\mathrm{~s}, 1 \mathrm{H}$, triazole $\mathrm{H}), 7.43(\mathrm{dd}, 1 \mathrm{H}, \mathrm{J}=2.3 \mathrm{~Hz}, 15.0 \mathrm{~Hz}$, phenyl $\mathrm{H}), 7.16(\mathrm{dd}, 1 \mathrm{H}, \mathrm{J}=2.3 \mathrm{~Hz}, 9.6 \mathrm{~Hz}$, phenyl H), $7.11(\mathrm{t}, 1 \mathrm{H}, \mathrm{J}=$ $9.1 \mathrm{~Hz}$, phenyl $\mathrm{H}), 5.11-5.17(\mathrm{~m}, 1 \mathrm{H}$, oxazolidinone $\mathrm{H}), 4.83(\mathrm{~d}, 2 \mathrm{H}$, $\mathrm{J}=4.99 \mathrm{~Hz}$, triazole $\left.-\mathrm{CH}_{2}\right), 4.21(\mathrm{t}, 1 \mathrm{H}, \mathrm{J}=8.7 \mathrm{~Hz}$, oxazolidinone $\mathrm{H}), 3.86$ (dd, $1 \mathrm{H}, \mathrm{J}=5.9 \mathrm{~Hz}, 9.1 \mathrm{~Hz}$, oxazolidinone H), 3.25 (br. s, $4 \mathrm{H}$, piperazine $\left[\mathrm{CH}_{2}\right]_{2}$ ), 3.17 (br. s, $4 \mathrm{H}$, piperazine $\left[\mathrm{CH}_{2}\right]_{2}$ ), MS $(\mathrm{m} / \mathrm{z}) 347.5$.

The degradation product of compound $1 \mathrm{~b}[(R)-3$-(3-fluoro4-(piperazinium-1-yl) phenyl-5-(4-methyl-1H-1,2,3-triazol-1-yl) methyloxazolidin-2-one hydrochloride] was similarly analyzed by ${ }^{1} \mathrm{H}-\mathrm{NMR} .{ }^{1} \mathrm{H}-\mathrm{NMR}$ (DMSO-d $\mathrm{d}_{6}, 600 \mathrm{MHz}$ ): $\delta$ 8.80-8.94 (br,
$2 \mathrm{H}$, piperazinium $\left.{ }^{+} \mathrm{NH}_{2}\right), 7.86(\mathrm{~s}, 1 \mathrm{H}$, triazole $\mathrm{H}), 7.44(\mathrm{dd}, 1 \mathrm{H}, \mathrm{J}=$ $2.3 \mathrm{~Hz}, 14.6 \mathrm{~Hz}$, phenyl H), $7.16(\mathrm{dd}, 1 \mathrm{H}, \mathrm{J}=2.4 \mathrm{~Hz}, 9.7 \mathrm{~Hz}$, phenyl $\mathrm{H}), 7.11(\mathrm{t}, 1 \mathrm{H}, \mathrm{J}=9.2 \mathrm{~Hz}$, phenyl $\mathrm{H}), 5.06-5.11(\mathrm{~m}, 1 \mathrm{H}$, oxazolidinone $\mathrm{H}), 4.73\left(\mathrm{~d}, 2 \mathrm{H}, \mathrm{J}=6.1 \mathrm{~Hz}\right.$, triazole- $\left.\mathrm{CH}_{2}\right), 4.19(\mathrm{t}, 2 \mathrm{H}, \mathrm{J}=$ $9.2 \mathrm{~Hz}$, oxazolidinone $\mathrm{H}$ ), $3.83(\mathrm{dd}, 1 \mathrm{H}, \mathrm{J}=5.9 \mathrm{~Hz}, 9.3 \mathrm{~Hz}), 3.25$ (br. s, $4 \mathrm{H}$, piperazine $\left[\mathrm{CH}_{2}\right]_{2}$ ), 3.18 (br. s, $4 \mathrm{H}$, piperazine $\left[\mathrm{CH}_{2}\right]_{2}$ ), $2.22\left(\mathrm{~s}, 3 \mathrm{H}\right.$, triazole- $\left.\mathrm{CH}_{3}\right), \mathrm{MS}(\mathrm{m} / \mathrm{z}) 361.5$.

\section{Results}

The HPLC chromatograms of solutions of TOZ compounds in the mobile phase exhibited well-resolved peaks at retention times between 4.0 and $6.0 \mathrm{~min}$ (fig. 2, 3 ). With the exception of compounds $1 \mathrm{a}$ and $1 \mathrm{~b}$, TOZ compounds showed good stability in simulated gastric medium, without any degradation at simulated $37^{\circ} \mathrm{C}$ (table 1). On the other hand, compounds $1 \mathrm{a}$ and $1 \mathrm{~b}$ underwent extensive degradation by acid hydrolysis. As shown in figure 2, the HPLC chromatogram of the acid-treated solution of compound la exhibited peaks of the TOZ compound and its acid-catalyzed degradation product at retention times 5.2 and $2.7 \mathrm{~min}$, respectively. The intensity of the degradation product peak progressively increased with time. However, at the 24-hour interval, compound la was completely degraded and only a major peak for the degradation product appeared in the chromatogram. A similar behavior was noted in case of compound $1 \mathrm{~b}$, where complete degradation was observed after $24 \mathrm{~h}$ incubation at $37^{\circ} \mathrm{C}$ (fig. 3). The chromatograph- 
Fig. 4. Acid-catalyzed hydrolysis of compounds $1 \mathrm{a}$ and $1 \mathrm{~b}$.
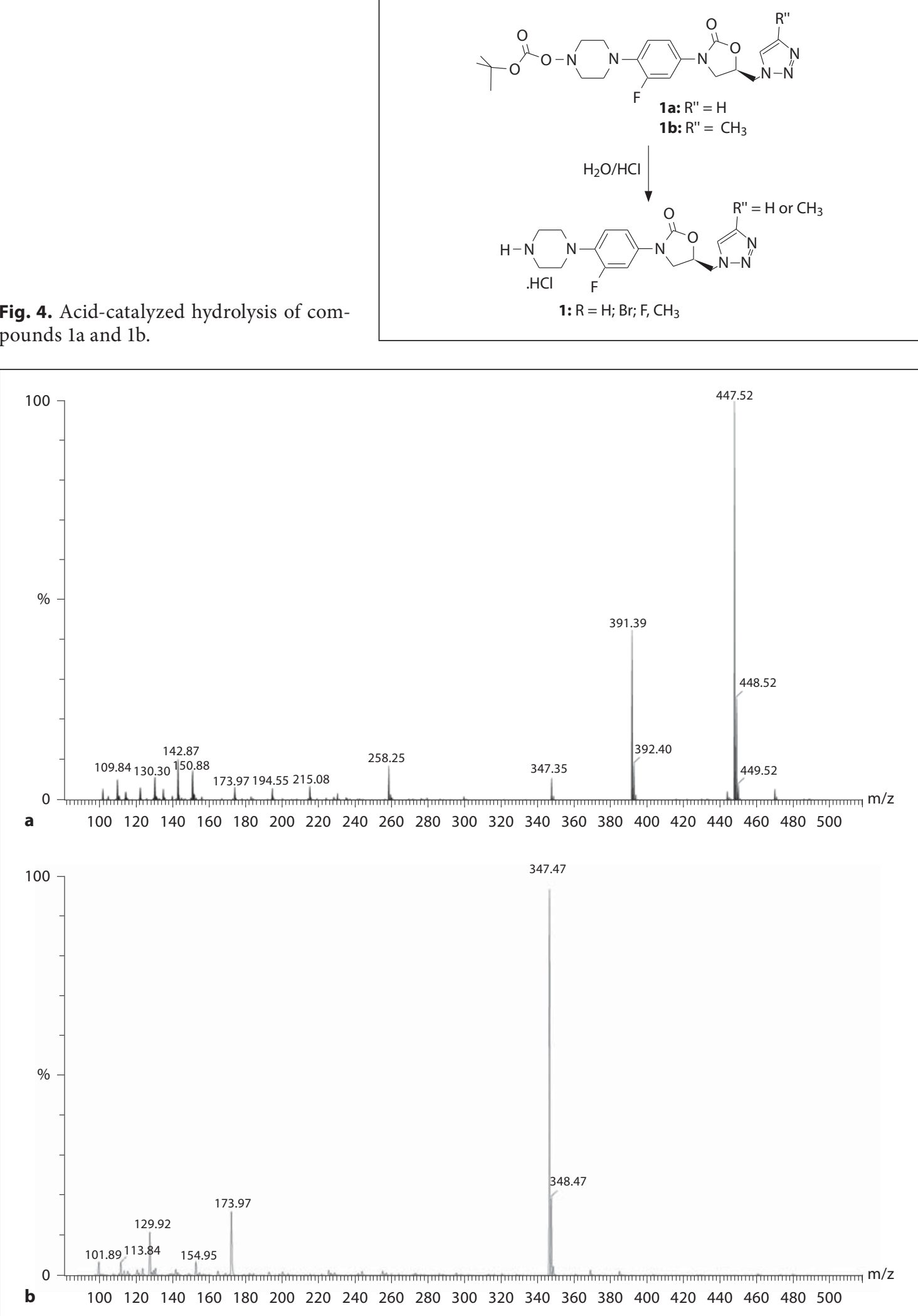

Fig. 5. MS scans of compound 1a (a) and degradation product of compound la (b). 
ic peaks of compound $1 \mathrm{~b}$ and the degradation product appeared at 5.5 and $2.7 \mathrm{~min}$, respectively. Only a single peak for the degradation product was also observed in the chromatogram. The degradation pathways involving the acid cleavage of the t-butoxycarbonyl group of the examined compounds were suggested as shown in figure 4 . A plot of the log\% compound remaining versus time indicated first-order kinetics. Upon application of the kinetic analysis, the degradation kinetic parameters $\mathrm{k}_{\text {deg }}, \mathrm{t}_{1 / 2}$ and $\mathrm{t}_{90}$ were found to be $0.180 \mathrm{~h}^{-1}, 3.85 \mathrm{~h}, 0.58 \mathrm{~h}$, respectively, for compound $1 \mathrm{a}$, and $0.184 \mathrm{~h}^{-1}, 3.76 \mathrm{~h}$ and $0.57 \mathrm{~h}$, respectively, for compound $\mathrm{lb}$ (table 1 ). The degradation products were further identified by MS analysis, with complete disappearance of the molecular masses of compounds $1 \mathrm{a}$ and $1 \mathrm{~b}$ at $\mathrm{m} / \mathrm{z} 447.7$ and 461.5, and the appearance of new molecular masses for the degradation products in MS at m/z 347.5 and 361.5. Representative mass spectra for compound la and its degradation product are shown in figure 5. The proposed chemical structures of the degraded products were in good agreement with MS data. On the other hand, the examined TOZ compounds were stable in phosphate buffer solutions and human plasma with remarkably low $\mathrm{K}_{\mathrm{deg}}$ and high $t_{1 / 2}$ and $t_{90}$ values (tables 2,3 ).

\section{Discussion}

The developed HPLC method proved to be a stabilityindicating procedure as it permits measurement of the examined TOZ compounds in the presence of their degradation products. However, it did not reveal the chemical structure of the degradation products, which could be identified by MS and confirmed by NMR analysis. The investigated oxazolidinones were remarkably stable in simulated biological fluids and human plasma at the simulated biological temperature of $37^{\circ} \mathrm{C}$, with the exception of compounds $1 \mathrm{a}$ and $1 \mathrm{~b}$. These $2 \mathrm{TOZ}$ compounds were completely degraded by acid hydrolysis in simulated gastric fluid within $24 \mathrm{~h}$ at $37^{\circ} \mathrm{C}$. This may be due to the presence of the carbamate functionality, which is relatively more sensitive to acid-catalyzed degradation [21], compared to the amide functionality present in the other piperazinyl derivatives studied. The pathways for the acid-catalyzed degradation of compounds $1 \mathrm{a}$ and $1 \mathrm{~b}$ were suggested. In case of compound $1 \mathrm{a}$, the degradation product was identified as (R)-4-[2-fluoro-4-(2-oxo-5$[1,2,3]$ triazol-1-yl methyl-oxazolidin-3-yl) phenyl]-piperazine-1-ium hydrochloride. The MS analysis indicated that the degradation product of compound $1 \mathrm{~b}$ is $(R)-3$ - (3-fluoro-4-(piperazinium-1-yl) phenyl-5-(4-methyl-1H1,2,3-triazol-1-yl) methyloxazolidin-2-one hydrochloride. The findings of this study suggest that the previously observed 4 -fold increase or greater MIC values for TOZ compounds, including $1 \mathrm{a}$ and $\mathrm{lb}$ in human plasma (pH about 7.4) [12-14] may therefore be attributed to protein-binding pharmacokinetic factors rather than to poor stability of the compounds in human plasma.

\section{Conclusion}

The investigated oxazolidinones were stable in simulated biological fluids and human plasma at $37 \pm 1{ }^{\circ} \mathrm{C}$, with the exception of the carbamate-containing oxazolidinones, 1a and $1 \mathrm{~b}$. These TOZs were completely hydrolyzed in simulated gastric fluid with subsequent loss of the antibacterial activity. The lower stability of compounds $1 \mathrm{a}$ and $1 \mathrm{~b}$ in gastric medium should be considered in formulation studies of these compounds for oral administration.

\section{Acknowledgement}

The authors wish to thank the Research Administration, Kuwait University for financial support through Research Grants PC01/05 (O.A.P), GS01/01, and GS03/01 (Science Analytical Facilities).

References $\longrightarrow 1$ Grau S, Rubio-Terrés C: Pharmacoeconomics of linezolid. Expert Opin Pharmacother 2008;9:987-1000.

-2 Drew RH: Emerging options for treatment of invasive, multidrug-resistant Staphylococcus aureus infections. Pharmacotherapy 2007; 27:227-249.

3 Wilcox MH: Update on linezolid: the first oxazolidinone antibiotic. Expert Opin Pharmacother 2005;6:2315-2326.

4 Moellering RC: Linezolid: the first oxazolidinone antimicrobial. Ann Intern Med 2003;138:135-142.

5 Bozdogan B, Appelbaum PC: Oxazolidinones: activity, mode of action, and mechanism of resistance. Int J Antimicrob Agents 2004;23:113-119.

-6 Sinclair A, Arnold C, Woodford N: Rapid detection and estimation by pyrosequencing of $23 \mathrm{~S}$ rRNA genes with a single nucleotide polymorphism conferring linezolid resistance in Enterococci. Antimicrob Agents Chemother 2003;47:3620-3622. 
7 Ippolito JA, Kanyo ZF, Wang D, Franceschi FJ, Moore PB, Steitz TA, Duffy EM: Crystal structure of the oxazolidinone antibiotic linezolid bound to the $50 \mathrm{~S}$ ribosomal subunit. J Med Chem 2008;51:3353-3356.

-8 Tsiodras S, Gold HS, Sakoulas G, Eliopoulos GM, Wennersten C, Venkataraman L, Moellering RB Jr, Ferraro MJ: Linezolid resistance in a clinical isolate of Staphylococcus aureus. Lancet 2001;358:207-208.

-9 Johnson AP, Tysall L, Stockdale MW, Woodford N, Kaufmann ME, Warner M, Livermore DM, Asboth F, Allerberger FJ: Emerging linezolid-resistant Enterococcus faecalis and Enterococcus faecium isolated from two Austrian patients in the same intensive care unit. Eur J Clin Microbiol Infect Dis 2002;21: 751-754.

10 Jones RN, Kohno S, Ono Y, Ross JE, Yanagihara K: ZAAPS International Surveillance Program (2007) for linezolid resistance: results from 5,591 Gram-positive clinical isolates in 23 countries. Diagn Microbiol Infect Dis 2009;64:191-201.

11 Phillips OA, Udo EE, Ali AAM, Al-Hassawi $\mathrm{N}$ : Synthesis and antibacterial activity of 5-substituted oxazolidinones. Bioorg Med Chem 2003;11:35-41.
12 Phillips OA, Udo EE, Ali AAM, Samuel SM: Synthesis and antibacterial activity of new N-linked 5-triazolylmethyl oxazolidinones. Bioorg Med Chem 2005;13:4113-4123.

13 Phillips OA, Udo EE, Ali AAM, Samuel SM: Structure-antibacterial activity of arylcarbonyl- and arylsulfonyl-piperazine 5-triazolylmethyl oxazolidinones. Eur Med Chem 2007;42:214-225.

14 Phillips OA, Udo EE, AbdelHamid ME, Varghese R: Synthesis and antibacterial activity of novel 5-(4-methyl-1H-1,2,3-triazole) methyl oxazolidinones. Eur Med Chem 2009;44:3217-3227.

15 Reck F, Zhou F, Girardot M, Kern G, Eyermann CJ, Hales NJ, Ramsay RR, Gravestock MB: Identification of 4-substituted 1,2,3-triazoles as novel oxazolidinone antibacterial agents with reduced activity against monoamine oxidase A. J Med Chem 2005;48:499506.

16 Hauck SI, Cederberg C, Doucette A, Grosser L, Hales NJ, Poon G, Gravestock MB: New carbon-linked azole oxazolidinones with improved potency and pharmacokinetics. Bioorg Med Chem Lett 2007;17:337-340.
Phillips OA, Abdel-Hamid ME, Al-Hassawi $\mathrm{N}$ : Determination of linezolid in human plasma by LC-MS-MS. Analyst 2001;126: 609-614.

18 Slatter JG, Stalker DJ, Feenstra KL, Welshman IR, Bruss JB, Sama JP, Johnson MG, Sanders PE, Hauer MJ, Fagerness PE, Stryd RP, Peng GW, Shobe EM: Pharmacokinetics, metabolism, and excretion of linezolid following an oral dose of $\left[{ }^{14} \mathrm{C}\right]$ linezolid to healthy human subjects. Drug Metab Dispos 2001;29:1136-1145.

19 Ji HY, Lee HW, Chang SG, Lee JJ, Rhee JK, Kim WB, Lee HS: Liquid chromatographytandem mass spectrometry for the determination of a new oxazolidinone antibiotic DA7867 in human plasma. Biomed Chromatogr 2004; 18:86-89.

20 Phillips OA, Abdel-Hamid ME: Determination of novel triazolylmethyl oxazolidinone concentrations in human plasma by APCILC-MS: application to stability study. J Pharmaceut Sci 2008;11:22s-31s.

21 Greene TW, Wuts PGM: Protective Groups in Organic Synthesis, ed 3. New York, Wiley, 1999, chapt 7, pp 503-550. 